\title{
Copyright Protection in Digital Era
}

\author{
Kanika Dawar ${ }^{1}$, Ashwin Sudarshan ${ }^{2}$, Dr. Chitra B T ${ }^{3}$ \\ ${ }^{1}$ UG - Mechanical Engineering, RV College of Engineering, Bangalore, Karnataka. \\ ${ }^{2} \mathrm{UG}$ - Mechanical Engineering, RV College of Engineering, Bangalore, Karnataka. \\ ${ }^{3}$ Assistant Professor, Industrial Engineering \& Management, RV College of Engineering, Bengaluru, Karnataka.
}

\begin{abstract}
The advent of the internet and advancement in technologies in the twentieth century raised a completely new set of challenges to the copyright domain. The digitization of content has brought about an astonishing increase in the distribution of unauthorised copyrighted works and has caused a tremendous impact on copyright law. Now that most forms of content are in digital format and are globally accessible, hence the need to protect the interest of the authors have risen over the decade. The paper reflects upon the copyright issues faced in the digital era which have been left unacknowledged. Further, this paper deliberates and analyses the problems faced by copyright holders due to circumvention of laws by people to access content illegitimately and also looking at judicial responses in the digital era which has been unaddressed. The paper concludes with some solutions and ideas that could be useful for regulating digital copyright infringement.
\end{abstract}

Keywords-Copyright, Digitalization, TRIPS Agreement, Indian Copyright Act, Digital Rights Management.

\section{INTRODUCTION}

Copyright is a right to intellectual property due to an individual's talent and labour in producing and transmitting an original concept. Copyright preserves works of heritage, such as literature, drama, musicals, and sculpture. Copyright is an exclusive lawful right provided to a creator or group of persons to protect their work or creativity from being reproduced, adapted, translated, distributed, or performed publicly without prior permission from the creator/person responsible for the work's existence. In India, Section 13 of the Copyright Act of 1957 establishes a list of protected works. According to the law, anybody who develops an original work has the exclusive right to duplicate it for a certain time. Originally, copyright applied to works that were sold and published. With the growth of technology, new challenges to existing copyright rules have arisen. As technology advanced to new heights, it made digital data more accessible, allowing for the exploitation of copyrighted works. Instantaneous duplication of original work is possible thanks to the Internet/digital media. Copyright is a fundamental problem in Intellectual Property Rights in the digital era.

\section{COPYRIGHT IN THE DIGITAL DOMAIN- INTERNATIONAL FRAMEWORK}

The influence of digitization on society is enormous. But, like they say that great inventions bring about great threats too, digitalisation, while playing a significant part in transforming society, has led to a number of other issues, such as infringement of a creator's or owner's rights through various means in the digital world. International organisations such as the World Intellectual Property Organization (WIPO) have played a crucial role in preventing the violation of these rights.The World Copyright Treaty of 1996 is an agreement specially established under the Berne Convention to safeguard works in the digital world. They are awarded three economic rights in surplus to the rights which are already considered by the Berne Convention of 1885, namely, the right to distribution, the right to rent, and the right to public communication. It ensures that every work created in the digital realm is protected for at least 50 years. Computer programmes and the compilation of data or material are two subject matters covered by the treaty that will be protected by Copyright (databases). The Copyright Act of 1957 protects copyright in India. Since then, numerous modifications have been made to fit the evolving requirements of society and to guarantee protection to the author's works. The primary goal of the act is to safeguard the authors' and copyright owners' works from unauthorised exploitation. The Copyright (Amendment) Act of 2012, which is regarded to be more significant, was recently enacted. The major goal of this legislation was to bring the act into compliance with the World Copyright Treaty of 1996 and the World Intellectual Property Organization's Performance and Phonogram Treaty of 1996. The Copyright Amendment Act of 2012 expanded its regulations for copyright protection in the realm of digitalization. It also included provisions for infringement fines, management information rights, internet service provider responsibility, and the establishment of statutory licences for cover versions and broadcasting planners. It also intended to ensure that revenues were distributed fairly among the work's authors and owners. The law also sought to make some acts exceptions, i.e., certain acts will not be considered infringement. Certain actions are defined in Section 52 of the Act as falling under the doctrine of fair use. This clause is in accordance with the Berne Convention of 1885 and the TRIPS Agreement of 1995. 


\section{International Advanced Research Journal in Science, Engineering and Technology}

Vol. 8, Issue 6, June 2021

DOI: $10.17148 /$ IARJSET.2021.86105

\section{COPYRIGHT ISSUES IN DIGITAL MEDIA}

The technologies relating to digital storage and transmission of works have been causing difficulties with copyright protection. The ease of replication and diffusion, for example, are two features of modern technologies that have ramifications for copyright law. The Internet has been one of the most challenging obstacles that Copyright has faced. Copyright protection varies depending on the information available on the internet. On the web, copyrighted works comprise news, articles, graphics, photographs, screenplays, and videos, among other things. Because of the vast amount of information available on the internet, determining whether a work is a duplicate or a copy of a protected work is challenging. It is a frequent misconception that material obtained over the internet that is in the public domain may be freely copied. Unless the information has been made public by the government, the copyright term has ended, or the copyright holder has renounced his claim, this is not the case. Digital piracy of copyrighted material has become commonplace. Computer software protection, digital rights management, technical circumventions, and other related concepts are gaining traction. The Copyright Act in India does not make ISPs liable for infringement of Digital Copyright. As a result, the Information Technology Act of 2000 was enacted to address the problem of ISP responsibility for infringement. 'No Service Provider was liable for an infraction committed or for violations that occurred without his knowledge provided the service provider used all reasonable care to prevent the violations,' it says.

\subsection{Fair dealing and anti-circumvention in India}

Section 52 of the Indian Copyright Act, as revised by the Copyright Amendment Act 2012, describes when reverse engineering is deemed fair usage and spells forth the legal position in India with regard to judicial discretion as a defence. Responsible treatment of any work that isn't a software application for secretive use, such as study, critique, or review of that work or any other work, coverage of current trends and market events, including the publication of a speech delivered in open, isn't a breach of the work. According to the interpretation to Section 52 (a), having any work in electronic media for obvious reasons specified in the stated contract includes infringement will not be committed because of accidental storage that is not itself an infringing copy. This demonstrates why cache should be considered fair use.

\subsection{Audio-visual Work}

In the worldwide context, an extension of protection may be offered as the internet offers audio-visual performances via music audios and videos, cinematographic works as well nowadays. This is also owing to the ability of digital technology to manipulate and distort actor pictures and voices, such as morphing, which is nothing more than the transformation of one image into another. The industry is concerned about the availability of pirated copies of films prior to their official release. In digital interactive television (iTV), viewers may utilise their own recorders for recording programmes by genre or actor, as well as stop and rewind, live television.

\subsection{Hyperlinked Text or Hot-linking}

The internet allows certain information to be linked facilities, with hypertext or a hyperlinked reference within the sites. The activation of the link is done by the user by clicking on the linked element, which is typically coloured or indicated differently compared to the rest of the document to indicate it is linked. Deep-linking refers to linking the user directly to secondary material on a different site, rather than the site's front or home page, which may constitute copyright violation in the material that is secondary. The phrase "embedded hyperlink," also referred to as in-line links, alludes to content from some other webpage so that the secondary material seems to be information from the primary website.

\subsection{Software Infringement}

A collection of computer procedures, programmes that carry out functions on computer systems are referred to as computer softwares. One of the most common causes of copyright infringement is software piracy. It entails the unauthorised copying and distribution of software that is copyrighted. Making a copy and selling it is what software piracy comprises; making a copy and exporting it; taking the software for rent; selling the hardware equipment of the computer consisting of the pirated software already installed, and copying software programmes using CD-R technology are all examples of software piracy.

\subsection{Social media}

Social networking platforms are becoming widely used methods of connecting people all over the world. These sites make it easier to share works that are potentially protected by intellectual property regulations. Copyright breaches have emerged from the popular habit of sharing content such as pictures and photographs on social media. The erroneous belief that all content published on social networking sites is open, which is driven by a lack of understanding of the status of copyright in this kind of material, is a primary source of such infringements. Copyright infringements on social networking platforms might consist of the following: Materials that are copyright-protected should not be re-posted, stored, or redistributed. Re-posting and easing ownership or creator rights of previously copyrighted work, as well as using the platform's material without the owner's authorization.

\subsection{Piracy}




\section{International Advanced Research Journal in Science, Engineering and Technology}

Vol. 8, Issue 6, June 2021

\section{DOI: $10.17148 / I A R J S E T .2021 .86105$}

Piracy is defined as the act of producing unauthorised or pirated copies and distributing or selling them. When work is pirated and distributed or sold, the authors, performers, phonogram and FDM producers' right to make copies is violated. It doesn't matter if the pirated copy is created from a genuine or a pirated copy of the work. As a result, copying, distributing, and selling an author's work is considered an act of infringement. The measure of piracy is whether the production's essence is unlawfully appropriated, not if similar terminology or terms are utilised. The situation in some countries is characterised as the "cycle of piracy," in which genuine copyright owners refuse to sell in the nation owing to the piracy problem, leaving the people with no choice but to turn to pirate. As a result, copyright holders' choice not to conduct business in the country is strengthened.

\subsection{Infringement of Copyright}

The essence of copyright law is that it prohibits profiting from and appropriating the labour, expertise, and capital of others. The creator of a work has exclusive privileges to particular forbidden acts at all stages of copyrighted and performance rights legislation. The person violates the copyright in that material if these acts are performed even without the permission of the publisher.

Section 2(m) of the Copyright Act of 1957 defines infringement as:

- Replication of a literary work, drama, musical, or artwork that is not a cinematographic film;

- In the case containing sound recordings, any other recording made by any means embodying the same sound recording;

- Under the scope of this Act, voice recordings or cinematic films of a broadcast or concert for which a broadcast reproduction right or an artist policy exists.

The extensive presence of the internet, as well as digitized use and innovations in copyright law, have dramatically transformed judicial theory with practice. People began discussing and sharing ideas and information on the World Wide Web. There are many challenges that the regime of digital copyright protection faces. Some of those challenges are in the fields of Copyright protection and involvement of the internet, Audio-visual work infringement, Hyperlinked text, Software and social media.

\section{PREVENTIVE MEASURES AGAINST DIGITAL COPYRIGHT INFRINGEMENT AND CIRCUMVENTION OF LAWS}

As a response to the easy reproduction and dissemination of works over the internet, copyright owners, with the help of technology have devised effective ways to restrain the use of their copyrighted material.

The most pressing copyright problem in the modern age can be classified into three categories:

(i) Databases and multimedia works, as well as computer programmes, are examples of wholly new types of labour.

(ii) Research associated with digital replication, dissemination, and broadcast streaming.

(iii) Copyright management and administration issues in the digital era.

\subsection{Novel works}

Innovation has previously fostered alternative technologies of artistic creativity in the visual industries, which were subsequently susceptible to copyright protection. Thus, the growth of photographers led to the establishment of "photographs," the introduction of analogue technology led to the creation of "phonograms," and the discovery of filmmaking led to the formation of a whole fresh batch of works such as cinematographic films, movies, and so on. The increased use of digital technology has also resulted in the emergence of certain distinguishable new works, such as computer programmes, databases, and multimedia works, which first prompted concerns regarding their copyright coverage.

\subsection{Computer works}

A sequence of instructions that allows a computer to do a specific function. that can indicate, perform, or achieve a given function, purpose, goal or outcome through information processing when included in a machine-readable media is known as a computer programme.

For a long time, the international community had been debating the most efficacious intellectual property rights regime for protecting computer programmes. Arguments for and against patent and copyright regimes, as well as a unique method to keep computer programs safe, were made. Following talks at the Uruguay Round of multilateral trade talks, the Agreement on Trade-Related Aspects of Intellectual Property Rights (TRIPS) implemented the stipulation that computer software, regardless of written in raw or object code, must be safeguarded as works of literature.

WCT later reiterated this, stating that computer programmes are protected regardless of the media or form in which they are conveyed. While the TRIPS Agreement of 1994 did not describe a clear position on conserving computer software as pieces of fiction under copyright rules, India still has one of the earliest laws that guaranteed ownership rights to software programs well before this Agreement. This was in accordance with the position of creative works in the Berne Convention, which stated that "any creation in the artistic, scholarly, or inventive sector, independent of style or mode of interaction" would be included. 


\section{International Advanced Research Journal in Science, Engineering and Technology}

Vol. 8, Issue 6, June 2021

DOI: $10.17148 /$ IARJSET.2021.86105

\subsection{Databases}

Another area of work that has been heavily changed by the advancements in digital innovations is database management. A database is an organized collection of resources, distinct works that are structured in a logical fashion and can be retrieved independently using digital or technological methods in the virtual environment. Manual data collection and database development was both cumbersome and inefficacious processes. Database development has never been easier or more user-friendly than it is now, thanks to digital technologies. The application that handles the data and the information itself are the two important characteristics of a computer database. The application will undoubtedly be safeguarded as a piece of literature. The programme will undoubtedly be preserved as a work of literature. Despite the Berne Convention's rules on compilations, many people had doubts about the content part's protection. As just a consequence, the TRIPS Agreement stated explicitly stated "Compilations of information as well as other materials that, as a result of this situation or organization of underlying contents, comprise artistic works must be safeguarded as being such, whether it be in computer-readable and perhaps another format."

\subsection{Multimedia Works}

A work may incorporate literary, artistic, musical, or dramatic aspects, as well as a phonogram or cinematographic film. The user can modify and update the workout, as well as create a new one from scratch. Electronic works integrate components from a variety of other sorts of artworks, including text, audio, static pictures, and visual media. The work that results transcend categorization. If the rights for all types of works were the same, this wouldn't have been such a big deal. However, in India, the law distinguishes between several classifications of works when it comes to rights. The ownership of a piece of literature varies markedly from those to cinematograph films. A literary work does not have a rental right, although a cinematographic film does have one. The standard of ownership, but on the other hand, differs between literary, theatrical, musical, and artistic works, which can be a problem. There is a school of thought that multimedia works should be categorised as computer programmes because they are digital products. Because the Copyright This could be a suitable alternative because the Act provides different rules for copyright and authorship of computer programmes vs literary works. A great number of multimedia compositions are being made by integrating previously completed works. The scenario will worsen when too many audiovisual compositions are generated as more complex ones.Fears of copyright infringement in the digital realm have prompted several preventative steps to uphold the rights and interests of the author or creator are protected. Techniques designed to govern the duplication, alteration, and dissemination of original works are suggested to as digital rights management. DRM solutions, according to authors and makers of creative artwork, are necessary to defend their rights by preventing free and unauthorised copying and dissemination of their work. Some of the most important DRM techniques are: Blockchain Innovation, Digital Watermarks and Access control and copy Control.

\section{JUDICIAL RESPONSES}

The traditional legal system has struggled to keep up with the rapid growth of the internet. To address the digital revolution, laws have been enacted all over the world. It will be impossible for the legislature or the courts to immediately establish effective remedies. However, amendments to existing laws and harmonisation for developed and developing countries have aided in resolving the above-mentioned problems with copyright in the digital domain.In Syed Asifuddin and ord v The State of Andhra Pradesh \& Anr [2005 CRLJ 4314], Employees of Tata Indicom got indicted on suspicion of trying to hack a computer source code under Section 65 of the Information Technology Act, 2000, which were only for use on the internet services of Reliance Infocomm. As per the tribunal, this code modification is indeed a felony offence. According to the court, a computer programme is a work of literature covered by copyright under Section 2(o), (ffc), sections 13 and 14 , and any infringement of a computer programme is penalized under Section 63 . The judge specifically stated, nevertheless, that once the material has already been provided, the question will be decided by the trial judge. Nonetheless, such change must not be deemed reasonable use under Section 52 of the Copyright Act 1957 as it was not back manufactured for any of the exemptions specified in Section 65A of the Copyright Amendment Act, 2012.SUPER CASSETTES INDUSTRIES LTD. V. YAHOO INC. \& ANR, CS(OS) 1124/2008Unlawful streaming of SCIL's copyright infringement on Yahoo's website multimedia has resulted in copyright violation, according to a complaint demanding a judicial ruling. Yahoo had claimed safety under the Digital Millennium Copyright Act (DMCA), asserting that if content providers contacted them, they could erase contributory infringement; nevertheless, this statute does not extend in India. The accuser and its workers, operatives, and caucuses are prohibited from replicating, adapting, disseminating, or redistributing the plaintiff's motion picture films, audio recordings, and/or underlying literary or artistic works in any way on their webpage, www.video.yahoo.com, and or intruding in any way on the plaintiff's cinematograph films, audio recordings, and/or fundamental musical composition works, in which the petitioner asserts possession.

\section{SUPER CASSETTES INDUSTRIES LIMITED V. YOUTUBE \& GOOGLE}

YouTube's policy, according to SCIL, promotes and profiteers from using copyright content shared online without getting a permit or permission from the actual content providers or repaying them in any way. The High Court issued an 


\section{International Advanced Research Journal in Science, Engineering and Technology}

Vol. 8, Issue 6, June 2021

DOI: $10.17148 / I A R J S E T .2021 .86105$

injunction over YouTube and Google, prohibiting them from duplicating, modifying, disseminating, transmitting, or presenting any audio-visual compositions that are the sole property of SCIL on their sites.

\section{SUPER CASSETTES INDUSTRIES LTD v. MY SPACE INC. \& ANR, 2011(48)PTC49(Del)}

Illegal display of copyright infringement in webpages through distribution, streaming of music, etc, which is a violation of their copyrighted property, was sought as an injunction. The court upheld the judgment based on the apex court's standards for granting interim injunctions, which provide that the court must evaluate the plaintiffs' case using three criteria: (a) prima facie case, (b) efficiency balancing, and (c) catastrophic harm. Defendant's reliance on its publications for revenues, harvesting the advantages of its interests for investment decisions, and so on was total.

THE CHANCELLOR, MASTER AND SCHOLARS OF THE UNIVERSITY OF OXFORD \& ORS. V. RAMESHWARI PHOTOCOPYING SERVICES AND ANR., CS (OS) 2439/2012

The lawsuit began with a common practice at Delhi University, in which copier shops copied book recommendations from prescribed textbooks and sold them at discounted prices. In 2012, Oxford University Press, University Of Cambridge Press (UK), and Taylor \& Francis Group (UK), as well as Cambridge University Press India Pvt. Ltd. and Taylor \& Francis Books India Pvt. Ltd., filed a lawsuit accusing copyright violations against Rameshwari Photocopy Service and the University of Delhi. The plaintiffs in the lawsuit were the Association of Students for Equitable Access to Knowledge (ASEAK) and the Society for Promoting Educational Access and Knowledge (SPEAK). The authors had to drop their cases against the plaintiffs after it was discovered that the store had a legitimate permit to operate on Delhi University's Campus Area. Having a reprographic licence was crucial for Rameshwari Photocopy Services since it gave them the right to do their business without causing any problems. According to the court, duplicating with the goal of sharing information and supporting education does not constitute copyright infringement, resulting in the University of Oxford withdrawing its cases.

\section{SUGGESTIONS AND CONCLUSION}

As a result of digital innovations, copyright protection has gotten increasingly complicated. It's critical to achieve an equilibrium between simple violation and costly prosecution, as well as the risks associated with international litigation. There is an increasing demand for international protection with the advancement of technology demanding the copyrighted material to be transferred across countries with the consent of the owner. The current fundamental regulations would be supplemented with a procedural framework for foreign lawsuits.

In India, the legislation controlling the copyright in "digital material," which includes computer programmes and software, is insufficient and ineffectual, necessitating further specific modifications to the present law. The "digital media" behemoths have assumed a key role, and the law is once again insufficient. This can be handled by either introducing new laws or amending existing regulations, both of which must conform to international law.

- As the internet has made the transmission of works across the borders without the consent of the owner quite effortless, a procedural mechanism for international litigation will be of help to execute already existing substantive provisions. An online licensing system could also work in bringing down data infringement and piracy.

- More clarity can be provided about the jurisdiction in cases of online copyright infringement. The laws are not specific about what will decide the jurisdiction in such cases.

- Ordinary users should be made aware of the know-how of copyright protection and infringement in order to reduce accidental infringements.

- The differences in procedures and laws for copyright infringement in states should be harmonized to develop uniform laws for the issues of cyberspace.

- The provisions' execution is a big issue, and there is a pressing need to enhance the judicial system for executing the legislation's requirements, which needs well-oiled enforcement technology.

- For the establishment and measurement of copyright violation legislation, as well as a shift in court attitudes tow ard copyright offences, a skilled and very well specialised police force is required.

\section{REFERENCES}

1.5 Leading Cases of Intellectual Property Rights (legalbites.in)

2. JIPR 2(1) (Copyright Enforcement in India).pdf.

3. http://nopr.niscair.res.in/bitstream/123456789/44436/1/JIPR\%2022(6)\%20303-310.pdf

4. http://www.ijhssi.org/papers/v2(4)/version-3/B240615.pdf.

5. https://www.oecd.org/sti/ieconomy/Chapter5-KBC2-IP.pdf.

6. https://files.eric.ed.gov/fulltext/EJ1221248.pdf

7. http://docs.manupatra.in/newsline/articles/Upload/040BB5AA-DE9A-4895-AA66-C82590E7BFF2.pdf.

8. Indian Copyright ACT 1957 as amended in 2012.

9. Mittal, R. (2006). From Printing Press to the Internet: The Stride of Copyright along with Technology, Intellectual Property and Technology Law Journal, 1, 21-46.

10. Hugenholtz, P.B. (1996). The Future of Copyright in a Digital Environment. Hague: Kluwer Law International. [4] Ficsor, M. (2002).

11. The Law of Copyright and the Internet. London, Oxford University Press.

12. Gulla, R. K. (2007). Digital Transformation of Copyright Laws and the Misty Indian Perspective, Icfai Journal of Intellectual Property Rights, $6(3), 1-26$. 


\section{International Advanced Research Journal in Science, Engineering and Technology}

Vol. 8, Issue 6, June 2021

\section{DOI: $10.17148 / I A R J S E T .2021 .86105$}

13. ShubhangiTaneja. "Implementing the Digital Learning". International Research Journal on Advanced Science Hub, 2, 6, 2020, 72-74. doi: 10.47392/irjash.2020.39

14. Sandy Ariawan; STIPAK Malang. "Building Critical Thinking in Covid-19 Pandemic Era: Impossible or I am Possible?". International Research Journal on Advanced Science Hub, 2, 6, 2020, 127-130. doi: 10.47392/irjash.2020.49

15. https://99designs.com/blog/tips/5-famous-copyright-infringement-cases.

16. Primavera de Filippi. Copyright Law in the Digital Environment: Private Ordering and the regulation of digital works. LAP LAMBERT Academic Publishing GmbH \& Co. KG, pp.116, 2012, 978-3-8484- 2022-3. ffhal-00713403f

17. WIPO, Model Provisions on the Protection of Computer Software, quoted in Steawart, supra, p 305.

18. Article 10.1 of TRIPS Agreement.

19. Article 4 of WCT

20. The definition proposed in Draft Article 2 of Basic Proposal. WIPO Document No CRNR/DC/6. This treaty has not yet been finalized.

21. Kavita, Jilova,C R (2015). Copyright in the digital age internet issues, Department of Law, Kurukshetra University. [http://hdl.handle.net/10603/100920]

22. Article 7(1)(2), Berne Convention, Berlin Text 1908.

23. Article 6bis, Berne Convention, Rome Text 1928.

24. Berne Convention for the Protection of Literary and Artistic Works (as amended on September 28, 1979)

25. Texts. Geneva: World Intellectual Property Organization, 1982. Print.

26. Irina Atanasova, 2019. "Copyright Infringement In Digital Environment," Economics \& Law, Faculty of Economics, SOUTH-WEST UNIVERSITY "NEOFIT RILSKI", BLAGOEVGRAD, vol. 1(1), pages 13-22.

27. WIPO General Information, WIPO Publication No 400 (E).

28. World Intellectual Property Organisation. (1967). Inside WIPO. WIPO. [https://www.wipo.int/about-wipo/en/]

29. World Intellectual Property Organisation. (1996). WIPO administered treaties. WIPO Performances and Phonograms Treaty. [https://www.wipo.int/treaties/en/ip/wppt/]

30. Thomas Z, Overview of changes to the Indian Copyright Law, Journal of Intellectual Property Rights, 17(2012) $324-334$.

31. Zingales N, Digital copyright, "Fair access" and the problem of DRM misuse, Boston College Intellectual Property \& Technology Forum, 2012, $1-36$.

32. http://cs.furman.edu/digitaldomain/themes/copyright/copyright4.html

33. Infringement of Copyright Law - An overview by Basharat; Heena, Kashmir University Law Review 2006 12(12): Pages 232-244.

34. Section 79, Information Technology Act, 2000,

35. The Impact of the Internet on Intellectual Property LawH'irn'. wipo.int/copyright/en/ecommerce/ip.../chap3.html

36. A linkage between a word, sentence, character, or graphic in a hypertext document and another element.

37. A link to a resource that is embedded within text or is associated with an image or an image map. Supra n. 9

38. WIPO. (1998). Intellectual Property Reading Material, WIPO, Geneva.

39. Gharami, Pradip, Ahmed, I G (2013). A critical study on infringement of copyright and its protection under the Copyright Law in WTO Regime, Department of Law, University of Calcutta. [http://hdl.handle.net/10603/172481]

40. Austin, Graeme W. (1999). Domestic Laws and Foreign Rights: Choice of Law in Transnational Copyright Infringement Litigation, Columbia VLA Journal of Law \& the Arts, 23, 1-46.

41. Schlachter, E. (1997). The Intellectual Property Renaissance in Cyberspace: Why Copyright Law Could Be Unimportant on the Internet, Berkeley Technology and Law Journal, 14, 1-25.

42. Ricketson, S. (1987). The Berne Convention for the Protection of Literary and Artistic Works: 1886-1986. London: Centre for Commercial Law Studies, Queen Mary College. 